\title{
Nomenclature adjustments to neglected syntaxa of the tall-herb hygrophilous communities of the SE-Europe
}

\author{
DMITAR LAKUŠIĆ 1 \\ VLADIMIR RANĐELOVIĆ 2 \\ ROMEO DI PIETRO ${ }^{3}$ \\ ${ }^{1}$ Institute of Botany and Botanical garden Jevremovac, \\ Faculty of Biology, University of Belgrade, \\ Takovska 43, 11000 Belgrade, Serbia. \\ E-mail: dlakusic@bio.bg.ac.rs \\ ${ }^{2}$ Department of Biology and Ecology, \\ Faculty of Sciences and Mathematics, \\ University of Niš, 18000 Niš, Serbia. \\ E-mail:vladar@pmf.ni.ac.rs \\ ${ }^{3}$ Department of Planning, \\ Design and Technology of Architecture, \\ Section Environment and Landscape, \\ Sapienza University of Rome, Via Flaminia 72 , \\ I-00196 Rome, Italy. \\ E-mail: romeo.dipietro@uniroma1.it
}

Corresponding author: Romeo Di Pietro

Keywords: Balkan vegetation, ICPN, Mulgedio-Aconitetea, Phytosociology, Syntaxonomy

Received April 12, 2015

Revised October 29, 2015

Accepted November 16, 2015.

\begin{abstract}
Background and Purpose: During the preparation of a coenological paper concerning the tall-herb vegetation of the Balkans, it emerged that some syntaxa were invalidly described in their original papers, while some other synataxa had been forgotten or considered invalid according to the current phytosociological literature even if they had been validly published in their original papers. The present study deals with the nomenclatural problems of the Rumicetalia balcanici Lakusici 1973, a neglected order of the montane tall-herb vegetation, and those of all its related lower-rank syntaxa.
\end{abstract}

Materials and Methods: All published papers that treated the nomenclatural issues regarding the tall-herb vegetation in the Balkans were analysed. The nomenclature adjustments were made in accordance with the rules of the Code of Phytosociological Nomenclature (ICPN). The original relevés presented in this paper were carried out using the Braun-Blanquet phytosociological approach.

Results and Conclusions: The nomenclature adjustments made in the paper result in the validation of the order Rumicetalia balcanicae and of four alliances: Rumicion balcanici, Ranunculion serbici, Cicerbition pancici and Petasition doerfleri. The validity of the alliance Cirsion appendiculati Horvat, Pawlowski et Walas 1937 was here confirmed while the name citation Geion coccinei Horvat in Quezel 1969 was here given for the first time. Finally several tall-herbs association were here validated and some others were proposed as new.

\section{INTRODUCTION}

The tall-herb vegetation of SE Europe has attracted researchers since

the beginning of the 20th century. The first botanist who studied this vegetation in the Balkan area was Adamović (1). Subsequently Horvat $(2,3,4,5,6)$ and Horvat et al. $(7,8)$ formally described several associations of tall-herbs for the Macedonian and Bulgarian mountains and classified them into two alliances: the Cirsion appendiculati $\mathrm{Ht}$., Pawl. et Walas 1937 and the Geion coccinei Horvat 1960. These alliances were included in the order Adenostyletalia Br-Bl. 1931 and in the class Betulo-Adenostyletea Br-Bl. 1931. Further studies were carried out by R. Lakušić (9, 10), R. Lakušić et al. (11) and R. Lakušić \& Redžić (12), who introduced four new alliances for the tall-herb vegetation: Petasition doerfleri Lakušić 1968, Rumicion balcanici Lakušić 1973, Ranunculion serbici Lakušić et al 1987 and Cicerbition pancicii Lakušić (1970) 1987. These alliances were originally included in the Balkan endemic order Rumicetalia balcanici Lakušić 1973 and subsequently moved 
into a different order, Cicerbidetalia pancicii Lakušić 1987. More recently some contributions regarding the syntaxonomy of the Balkan tall-herb vegetation were carried out by Ranđelović \& al (13), Ranđelović (14), Ranđelović \& Zlatković (15). On the basis of the presumed nomenclatural invalidity of the name Rumicetalia balcanici, and in accordance with the concepts already expressed by R. Lakušić, these authors described the new order Cirsietalia appendiculati V. Ranđelović 2001. Several other studies, dealing with the tall-herb vegetation were subsequently published for the Balkan Peninsula $(16,17,18,19,20$, $21,22,23,24,25,26)$. Despite this high number of published papers, in which several new nomenclatural proposals were made, the majority of the associations and alliances proposed for classifying the Balkan tall-herb vegetation remained invalidly published. The nomenclatural adjustments that will be made in the present paper lead to: 1) the validation of the order name Rumicetalia balcanici; 2) the validation of some Balkan tall-herb associations and alliances linked to this order.

\section{MATERIALS AND METHODS}

All published papers that treated the nomenclatural issues regarding the tall-herb vegetation in the Balkans were analysed. Nomenclatural adjustments were made according to the International Code of Phytosociological nomenclature ICPN (27). Regarding the authorship of the syntaxa Radomir Lakušić is reported simply as "Lakušić", while Dmitar Lakušić is reported as D. Lakušić. The name Ranđelović make always reference to Vladimir Ranđelović both in the text and in the syntaxa names. The nomenclature of the plant species followed EURO+MED plant base (28). For those plant families and genera which were currently still not included in the EURO+MED database reference was made to Flora Europaea (29).

The term "transgr" make reference to the "transgressive species" according to the definition given in (30).

\section{RESULTS AND DISCUSSION}

\section{Order rank}

The name Rumicetalia balcanici was proposed for the first time in R. Lakušić (10: page 31) to classify the tallherb Balkan endemic vegetation developed on the hydrogenic soils of the siliceous massifs. This order was originally composed of three alliances reported as follow: "Cirsion appendiculati Horvat", "Geion coccinei Horvat" and "Rumicion balcanici Lakušić". Since in (10) there were no Horvat's papers quoted in the reference list the first two names were simply phantom names (Art. 2b) and none of these could be selected as nomenclatural type for the new order Rumicetalia balcanici. For the same reason (Art. 2b) also the name Rumicion balcanici Lakušić was to be considered as invalid. As a consequence the name
Rumicetalia balcanici Lakušić 1973 had to be considered invalidly published in its first proposal. This name, however, was gradually forgotten by the Balkan phytosociologists, who preferred to make reference to other names. Up to 1987 the Balkan high-altitude tall-herb communities tended to be classified in the Adenostyletalia $(8,31)$ or in the Montio-Cardaminetalia Pawl. 1938 (18,33). Only with R. Lakušić et al. (11) was the old concept of an endemic order restricted to the tall-herb vegetation of the Balkans reaffirmed. As regards the name of this order, however, in (11) the authors did not opt for the name Rumicetalia balcanici, but introduced the reference to a new name: Mulgedietalia pancicii Lakušić 1970. Since none of R. Lakušićs papers published in 1970 (or in the surrounding years) makes reference to the name Mulgedietalia pancici, this name (Mulgedietalia pancici Lakušić 1970 ) is probably to be considered a phantom name. From a coenological point of view the Mulgedietalia pancici were partially different from the Rumicetalia balcanici, since Mulgedietalia also included the basiphilous tall-herb communities developed on limestone bedrocks, whereas the Rumicetalia balcanici (10) was restricted to the three acidophilous alliances Rumicion balcanici, Cirsion appendiculati and Geion coccinei. The greater ecological amplitude which characterized the Mulgedietalia pancici as compared to the Rumicetalia balcanici, was supported by the inclusion in this order of three further alliances: Petasition doerfleri Lakušić 1968, Mulgedion pancicii Lakušić 1970 and Ranunculion serbici Lakušić et al. 1987. The name Mulgedietalia pancici Lakušić, Mišić, Golić 1987, however, is not validly published (Art. 2b) in (11) since this paper lacks of an unambiguous reference to an earlier, effectively published, sufficient diagnosis of both the Cirsion appendiculati Horvat et al. 1937 and the Geion coccinei Horvat in Quezel 1969, these latter being the only valid published alliances included in the Mulgedietalia pancici by Lakušić, Mišić, Golić (11). Some years later R. Lakušić \& Redžić (12) corrected the name Mulgedietalia pancicii in Cicerbidetalia pancicii Lakušić 1978 and the name Mulgedion pancici Lakušić 1978 in Cicerbition pancici nomen novum. In addition to being invalid (Art. 5), the name Cicerbidetalia pancicii was clearly a syntaxonomical synonym of the Rumicetalia balcanici Lakušić 1973, since it included the three alliances (Rumicion balcanici, Cirsion appendiculati and Geion coccinei) which were originally classified in the Rumicetalia balcanici.

The invalidity of the names Rumicetalia balcanici, Mulgedietalia pancicii, and Cicerbidetalia pancicii led Ranđelović (14) and Ranđelović \& Zlatković (15) to propose the new order Cirsietalia appendiculati V. Randj. 2001 (nom. inval. Art. 1; 3i) to classify all the Balkan tall-herb communities developed on the hydromorphic siliceous soils of the subalpine-alpine belt. Since these authors included the alliances Cirsion appendiculati, Geion coccinei and Rumicion balcanici in the new order Cirsieta- 


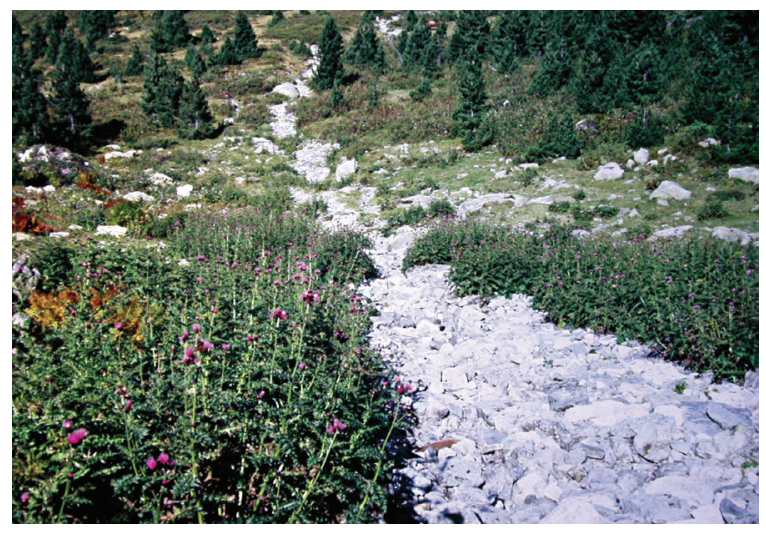

Fig. 1 - Community with dominance of Cirsium appendiculatum - All.: Cirsion appendiculati (Typus of Rumicetalia balcanici) Serbia, Kosovo, Mt. Šar-planina, Jažinačko jezero, c. 1900 m, silicate (photo: D. Lakušić 10.07.1990)

lia appendiculati, this latter can be considered as perfectly overlapping the Rumicetalia balcanici Lakušić 1973.

These reiterated proposals for the establishment of an endemic Balkan order for the high-altitude tall-herbs vegetation were justified on the basis of the strong Balkan endemic floristic component which occurs in this vegetation type. Moreover many of these Balkan endemic species play a dominant coenological role in their communities (e.g. Aconitum burnatii subsp. pentheri, Aconitum toxicum. subsp. bosniacum, Alchemilla viridiflora, Angelica pancicii, Aquilegia blecicii, Barbarea balcana, Cardamine acris, Cardamine amara subsp. balcanica, Cicerbita pancicii, Cirsium appendiculatuim, Cirsium boujartii subsp. wettsteinii, Cirsium heterotrichum, Doronicum austriacum subsp. giganteum, Geum coccineum, Geum rhodopeum, Heracleum sphondylium subsp. verticillatum, Hesperis dinarica, Knautia sarajevensis, Linaria peloponnesiaca, Lunaria telekiana, Ranunculus serbicus, Rumex balcanicus, Senecio pancicii, Silene asterias, Willemetia stipitata subsp. albanica etc.). Such coenological dominance is rather unusual, especially for those plant communities developed on the hydrophilic siliceous bedrock where the circumboreal and central-European species tend to monopolize the floristic composition (see 34). For this reason we have decided to propose again the concept of a Balkan endemic order for the tall-herbs communities developed between the montane and the lower alpine altitudinal belts. Accordingly we validate here the name Rumicetalia balcanici R. Lakušić ex Lakušić, Ranđelović \& Di Pietro ord nov. hoc loco.

$\Rightarrow$ Rumicetalia balcanici Lakušić ex D. Lakušić, Ranđelović \& Di Pietro ord. nov. hoc loco

(Mulgedio-Aconitetea)
[Orig: Rumicetalia balcanici Lakušić 1973 (art. 2b); = Mulgedietalia pancici Lakušić 1970 (phantom); Mulgedietalia pancici Lakušić, Mišić, Golić 1987 (art. 2b) Cicerbidetalia pancici Lakušić \& Redžić 1989 (art. 5); Cirsietalia appendiculatii Ranđelović 2001 (art. 1) Cirsietalia appendiculatii Ranđelović ex Ranđelović \& Zlatković 2010 (art. 3i)]

NAme-Giving species: Rumex balcanicus Rech. fil.

Typus: Cirsion appendiculati Horvat, Pawlowski et Walas 1937

Diagnostic taxa: Angelica pancicii, Barbarea balcana, Cardamine acris, Cardamine amara subsp. balcanica, Lactuca pancicii, Cirsium appeniduclatum, Cirsium boujartii subsp. wettsteinii, Doronicum austriacum subsp. giganteum (=Doronicum orphanidis Boiss.), Geum coccineum, Heracleum sphondylium subsp. verticillatum, Ranunculus serbicus, Rumex balcanicus, Silene asterias.

Constant taxa: Caltha palustris subsp. laeta, Chaerophyllum hirsutum agg., Deschampsia cespitosa, Filipendula ulmaria, Myosotis palustris, Veratrum lobelianum.

DiAgnosis: Tall-herb vegetation developed on different substrates occurring within an altitudinal gradient ranging from the lower-montane to the lower alpine belts.

Distribution: Central, eastern and southern part of the Balkan peninsula, in the territories of Bosnia and Herzegovina, Serbia and Kosovo, Montenegro, Albania, Bulgaria, Macedonia and Greece. From a synchorological viewpoint the Rumicetalia balcanici vegetation belong to three main Balkan biogeographical provinces: Illyrian (Dinaric Mts.), Moesian (Balkan and Rhodopaean Mts.) and Scardo-Pindian (Scardian and Pindian Mts.).

\section{Alliance rank}

$\Rightarrow$ Cirsion appendiculati Horvat, Pawlowski et Walas 1937

\section{(Rumicetalia balcanici, Mulgedio-Aconitetea)}

\section{Name-giving species: Cirsium appendiculatum}

Typus: Angelico-Heracleetum verticillati Horvat, Pawlowski et Walas 1937 (7: 186)

Diagnostic taxa: Cirsium appeniduclatum (transgr.), Cirsium thymphaeum, Angelica pancicii (transgr.), Heracleum sphondylium subsp. verticillatum (transgr.), Doronicum austriacum subsp. giganteum (=Doronicum orphanidis Boiss.) (transgr.)

Constant taxa: Athyrium filix-femina, Alchemilla indivisa, Caltha palustris subsp. laeta, Carduus personata, Chaerophyllum hirsutm, Chaerophyllum aureum 
var. balcanicum, Deschampsia cespitosa, Geranium sylvaticum, Milium effusum, Myosotis palustris, Myosotis scorpioides, Rumex alpinus, Rumex arifolius, Saxifraga rotundifolia s.l., Senecio nemorensis, Stelaria nemorum, Telekia speciosa, Veratrum lobelianum.

Diagnosis: Lime-poor substrates, within the subalpine mountain streams banks occasionally affected by turbulent water flows and floristically characterized by true tall-herb species (Fig. 1).

Distribution: The Cirsion appendiculati occurs in Serbia (Mt. Stara planina, Vlasina Plateau and Krajište region - Balkan-Rodopaean system), Kosovo (Mt. Šarplanina - Scardo-Pindian system), Macedonia (Mts. Bistra, Pelister - Scardo-Pindian system), Greece (N Pind, Mt. Bela Voda - Scardo-Pindian system) and Bulgaria (Mts. Vitoša, Rila, Pirin - Rodopaean system).

Syntaxonomy and nomenclature: In Horvat et al. (7) the following two associations were considered as included in the new alliance Cirsion appendiculati: Ass. with Angelica pancicii and Heracleum verticillatum (from Rila Mts.) and the "Cirsium appendiculati and Caltha laeta. ass." (from Macedonia). This latter had been invalidly (Art. 2) proposed by Horvat in (3) and subsequently proposed again in (5) with the name Doronico orphanidis-Cirsietum appendiculati (nom. inval. art. 2). The phytosociological table (table VI) presented in (7: page 184-185) is very complex and heterogeneous. Of the three relevés which the author included in the alliance Cirsion appendiculati, the first two were classified in the Angelica and Heracleum ass. and all the species reported in these two relevés exhibited coverabundance indexes. The third relevé, on the other hand, was included in the Cirsium and Caltha ass. and did not exhibited the cover-abundance indexes. As a consequence the Cirsium and Caltha ass. is to be considered invalid (art. 7), while the Angelica and Heracleum ass. (Angelico pancici-Heracleetum verticillati Horvat et al. 1937) is validly described and, since it is the only element suitable for the typification of Cirsion appendiculati it automatically assumes the role of holotypus for this alliance. The lectotypus of the Angelico pancici-Heracleetum verticillati Horvat et al. 1937 was provided by Roussakova (21: page 112) using rel. 2 of table VI in Horvat et al. 1937 (7). This lectotypification is valid and in accordance with Art. 5. Čarni \& Matevski (23) page 163 provided a lectotypification of the name Cirsion appendiculati using the name Doronico austriaci-Cirsietum appendiculati Horvat ex Čarni \& Matevski 2010, this latter being a validation of Horvat's invalid name Doronico orphanidis-Cirsietum appendiculati. The typus of Doronico austriaciCirsietum appendiculati Horvat ex Čarni \& Matevski 2010 was selected using the rel. 1 of Table VI in Horvat et al. 1937. In the same paper (23) the authors designeted the Doronico austriaci-Cirsietum appendicu- lati Horvat ex Čarni \& Matevski 2010 as the lectotypus of the name Cirsion appendiculati Horvat et al. 1937. In doing this they were making a neotypification. However, this typification was superfluous, as the original diagnosis of the alliance already contained one element (Angelico-Heracleetum verticillati) serving as the holotype. What is more this typification would anyway have been invalid (Art. 5), due to the English word "lectotype" being used in a paper published after 2002. Moreover the name Doronico orphanidis-Cirsietum appendiculati had alerady unintentionally been validated by Quezel in (26), where the author presented a phytosociological table of this community composed of three relevès sampled in the Bela Vode massif in N-Greece. Thus the correct name of the association should be read as Doronico gigantei-Cirsietum appendiculati Horvat ex Quezel 1969 (According to Euro + Med Plant base (28) Doronicum orphanidis Boiss. is to be considered a synonym of Doronicum austriacum subsp. giganteum (Griseb.) Stoj. \& Stef. while according to (32), which was used in Čarni \& Matevski (23), the same taxon is a synonym of Doronicum austriacum Jacq.). In the present paper the lectotypus of the Doronico gigantei-Cirsietum appendiculati Horvat ex Quezel 1969 is designated selecting rel. 3 of Tab. 2 at page 98 in Quezel 1969 (26). As a consequence the Doronico austriaci-Cirsietum appendiculati Horvat ex Čarni \& Matevski 2010 is to be considered an illegitimate name (Art. 31). The Angelico-Heracleetum verticillati Horvat et al. 1937 and the Doronico austriacae-Cirsietum appendiculati Horvat ex Čarni \& Matevski 2010 (nom illeg.) were each typified using a different one of the two relevés occurring in the phytosociological table VI in Horvat et al. 1937. The two relevés are quite similar to each-other, since they were both sampled in the Rila mountains, and are therefore presumably to be considered as belonging to the same association. The Angelico pancici-Heracleetum verticillati Horvat, Pawlowski et Walas 1937 and the Doronico austriaci-Cirsietum appendiculati Horvat ex Čarni \& Matevski 2010 should therefore be treated as syntaxoniomical synonyms with nomenclatural priority given to the Angelico-Heracleetum. The association name Angelico pancici-Heracleetum verticillati, however, appears to be inappropriate, especially in the light of the cover-abundance values of the species occurring in the type-relevé of the association, where both Angelica pancici and Heracleum verticillatum cover less than $1 \%(+)$. However, despite this, the name Angelico-Heracleetum is valid and in accordance with the rules of ICPN (Pr. IV, Art. 7 and 29b). Nevertheless Čarni \& Matevski (23) were probably right when they said that the most plausible name of the association should be Doronico austriaci (gigantei)-Cirsietum appendiculati. In fact, Horvat et al. (7) described the association as "rich in Doronicum orphanidis $(=D$. austriacum) and Cirsium appendiculatum" and this was supported by the fact 
that in the original table these two species exhibited cover-abundance values of, respectively, 4 and 3 in the type relevé of the Doronico-Cirsietum, and of 2 and 3 in the type-relevé of the Angelico-Heracleetum.

The following associations are currently included in the Cirsion appendiculati

- Angelico-Heracleetum verticillati Horvat, Pawlowski et Walas 1937

- Doronico gigantei-Cirsietum appendiculati Horvat ex Quezel 1969

- Geo coccinei-Rumicetum alpini Čarni et Matevski 2010

- Veratro lobeliani-Cirsietum tymphaei Quezel 1967 (Lectotypus hoc loco designatus: rel. 9 Tab. 19 in Quezel 1967 (25).

- Chaerophyllo hirsuti-Cirsietum oleracei Ranđelović ex D. Lakušić, Ranđelović \& Di Pietro ass. nov. hoc loco

- Veratro lobeliani-Cirsietum helenioidei Ranđelović ex D. Lakušić, Ranđelović \& Di Pietro ass. nov. hoc loco - Filipendulo ulmariae-Cirsietum apendiculati Ranđelović ex D. Lakušić, Ranđelović \& Di Pietro ass. nov. hoc loco

$\Rightarrow$ Geion coccinei Horvat in Quezel 1969

(Rumicetalia balcanici, Mulgedio-Aconitetea)

Basyonim: Geion coccinei Horvat 1960, (Art. 2)

Name-giving sPecies: Geum coccineum

Typus: Geo coccinei-Deschampsietum caespitosae Horvat ex Quezel 1969 (26: 98-100)

Diagnostic taxa: Alchemilla viridiflora, Cirsium heterotrichum, Geum coccineum (transgr.), Geum rhodopeum, Potentilla aurea subsp. chrysocraspeda, Pseudorchis frivaldii, Senecio pancicii, Silene asterias (transgr.).

Constant taxa: Agrostis canina, Alchemilla gracilis, Caltha palustris subsp. laeta, Chaerophyllum hirsutum agg., Crepis paludosa, Deschampsia cespitosa, Equisetum palustre, Filipendula ulmaria, Galium palustre, Geum rivale, Juncus effusus, Juncus thomasii, Mentha longifolia, Myosotis palustris, Potentilla erecta, Scirpus sylvaticus, Veratrum lobelianum.

Diagnosis: The Geion coccinei communities are developed in the subalpine belt of the W-Balkan-Rhodopean and N-Scardo-Pindian mountains on lime-poor substrates characterized by a constant water flooding (Fig. 2).

Distribution: The Geion coccinei occurs in Serbia (Mt. Stara planina, Vlasina Plateau and Krajište region - Balkan-Rodopaean system), Kosovo (Mt. Šarplanina - Scardo-Pindian system), Macedonia (Mts. Bistra, Jablanica, Pelister - Scardo-Pindian system), Albania (Mt. Lure - Scardo-Pindian system), Greece
(Mt. Bela Voda - Scardo-Pindian system) and Bulgaria (Mts. Vitoša, Rila, Pirin - Balkan-Rodopaean system).

Syntaxonomy and nomenclature: Although the Balkan phytosociological literature is not in agreement as regards the date of first publication of this alliance [1949 in (31, 36); 1937 in (15)], the correct nomenclatural reference is "Horvat 1960" (5). In fact, the date "1949" refers to the unpublished manuscript: "HORVAT, I. 1949: Mountains vegetation of Macedonia. Manuscript - in Macedonian with German summary" and not to the textbook which in the present paper is reported as (4). In (5) the Geion coccinei was defined as an alliance including the marshy meadows developed on the subalpine belt of the siliceous mountains of Macedonia. In (5) the author provided only a short, informal description of the alliance, which in that moment he considered as including the only CoccineoDeschampsietum and highlighted that the systematic position of the Geion coccinei in the Adenostyletalia was still provisional. It is interesting, however, that Horvat used the term "marshy meadow" for the Geion cocci$n e i$ in the place of "tall-herb vegetation", which he always used to describe the communities of the Cirsion appendiculati. In "Vegetation Südosteuropas" (8) the reference to the name Geion coccinei was given as provisional (page 581) even if Horvat was one of the authors of the book. Horvat (1897-1963) died only three years after the publication of the work in which he gave the first diagnosis of the alliance Geion coccinei Horvat 1960, while the book "Vegetation Südosteuropas" was published in 1974 and was edited by Glavač and Ellenberg. It is possible, therefore, that the decision to consider the Geion coccinei as a "special alliance, but still unclear" (page 583), was taken by Glavač and Ellenberg, probably due to the lack of available phytosociological data. The lack of a precise reference to the Geion coccinei in (8) was probably the reason for which this name was also overlooked in the overview on the European phytosociological alliances carried out by Rodwell et al. (35).

Summarizing the name Geion coccinei was (invalidly) proposed (art. 1) for the first time in 1949 (Horvat's hand-written manuscript) and the subsequent proposal of 1960 (5) was invalid, too (art. 2b). The Coccineo-Deschampsietum Horvat 1935 (the only association included in the alliance) was invalidly described in the original paper (2) and was not validated in (5) since neither a phytosociological table nor a single relevé usable as nomenclatural type was published in either of the papers. Notwithstanding this nomenclatural shortcoming, the names Geion coccinei Horvat 1949 and Geion coccinei Horvat 1960 were kept as syntaxonomical reference by many authors in subsequent vegetation surveys concerning Serbia, Macedonia and Greece $(14 ; 15,23,31,36,37)$. The association name Geo 
coccinei-Deschampsietum caespitosi Horvat 1935 and the alliance name Geion coccinei Horvat 1960, however, were unintentionally validated in Quezel (26), where a survey on the vegetation of the Bela-Vode massif (NGreece) was presented. In his paper (26: page 99), Quezel identified an "association à Deschampsia caespitosa et Geum coccineum" (making direct reference to the original paper (2) in which Horvat had described the association) and included it in the alliance Geion coccinei Horvat 1949. In the same paper (26) Quezel also presented a phytosociological table (page 98) in which three relevès were classified as belonging to the Deschampsia caespitosa and Geum coccineum association and to the alliance Geion coccinei. In this table the list of the characteristic species (identical for both the association and the alliance) was also given. In the bibliography of the paper references to $\operatorname{Horvat}(2,3,5)$, and Horvat et al. (7) were reported. As a consequence the association Geo coccinei-Deschampsietum caespitosae Horvat ex Quezel 1969 is to be considered as validly published (art. 2; 6). In the present paper we designated the lectotypus of this association selecting rel. 6, table 2 (page 98) in (26). However the situation regarding the correct author citation for the name Geion coccinei is different. In fact, Quezel (26) cited the Geion coccinei Horvat 1949 in the text, but failed to quote Horvat (1949) in the reference list of his paper. Therefore, in (26) there is no validation of the alliance Geion coccinei, but rather a description of a new alliance where the correct name of this latter is Geion coccinei Horvat in Quezel 1969.

The following associations are currently included in the Geion coccinei:

- Geo coccinei-Deschampsietum caespitosae Horvat ex Quezel 1969

- Carici-Deschampsietum caespitosae Roussakova 2000

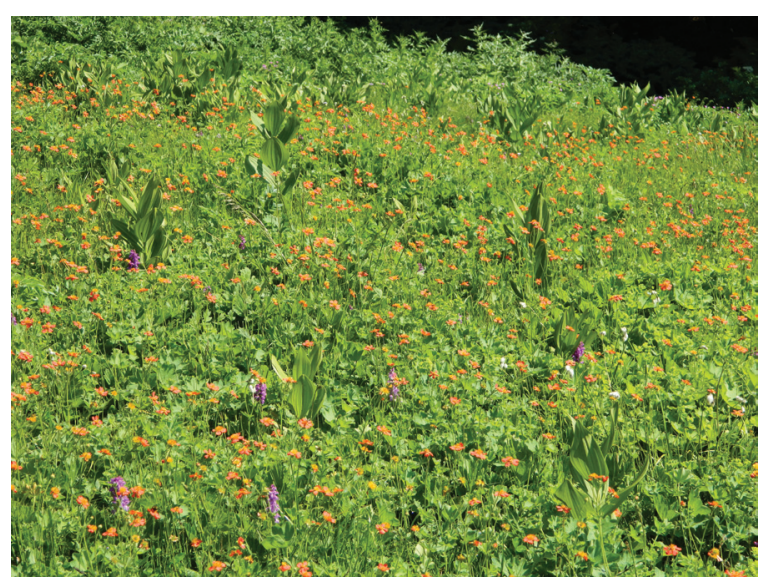

Fig. 2 - Community with dominance of Geum coccineum - All.: Geion coccinei. Macedonia, Mt. Jablanica, Krstec, c. 1700 m, silicate (photo: Randelovic, V., 20.06.2013)
- Trollio europaei-Geetum rhodopaei Ranđelović ex D. Lakušić, Ranđelović \& Di Pietro ass. nov. hoc loco - Geo rivali-Filipenduletum ulmariae Ranđelović ex D. Lakušić, Ranđelović \& Di Pietro ass. nov. hoc loco

$\Rightarrow$ Rumicion balcanici Lakušić ex D. Lakušić, Ranđelović \& Di Pietro all. nov. hoc loco

(Rumicetalia balcanici (Montio-Cardaminetea?), Mulgedio-Aconitetea)

Basyonim: Rumicion balcanici Lakušić 1973, (Art. 2)

NAME-GIVING SPECIES: Rumex balcanicus

Typus: Barbareo balcanae-Rumicetum balcanici V. Randjelović ex D. Lakušić , Ranđelović \& Di Pietro ass. nov. hoc loco

Diagnostic taxa: Barbarea balcana (transgr.) Cardamine amara subsp. balcanica (transgr.) Dactylorhiza cordigera subsp. bosniaca, Pinguicula balcanica, Rumex balcanicus (transgr.) Willemetia stipitata subsp. albanica.

Constant taxa: Barbarea balcana, Caltha palustris subsp. laeta, Cardamine amara subsp. balcana, Cardamine matthioli, Carex flava, Carex nigra, Chaerophyllum hirsutum agg., Crepis paludosa, Dactylorhiza cordigera subsp. cordigera, Deschampsia cespitosa, Epilobium palustre, Filipendula ulmaria, Myosotis palustris, Rumex balcanicus, Veratrum lobelianum.

Diagnosis: Tall-herb communities of the upper-montane and subalpine belts of the SE-Dinarids, W-BalkanRhodopean and N Scardo-Pindian mountains. The alliance is characterized by a mixture of tall-herbs and species coming from the meso-hygrophilous grasslands, cryo-hygrophilous peat-bogs and cold oligotrophic springs. The Rumicion balcanici communities can be found on the lime-poor substrates developed nearby the mountain creeks as well as on the humid mild slopes where a high degree of water retention occurs (Fig. 3).

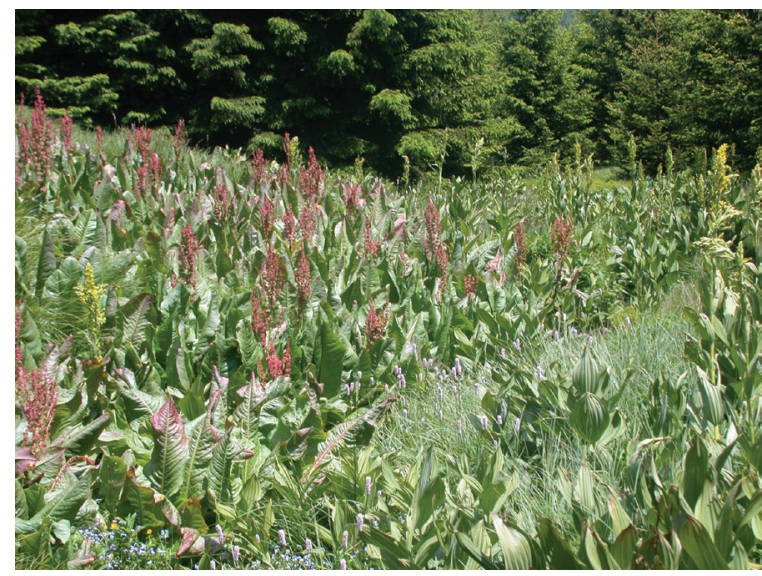

Fig. 3 - Ass. Brachythecio rivulare-Rumicetum balcanici $V$. Randjelović ex D. Lakušić et al. ass. nov. All. : Rumicion balcanici. Serbia, Mt. Čemernik, c. 1350 m (photo: Randelović, V., 23.06.2011) 
Fig. 4 : Distribution area of Rumex balcanicus. 1. Mt. Bjelasica, 2, Mt. Prokletije, 3. Mt. Kopaonik. 4. Mt. Stara planina, 5. Mt. Čemernik, 6. Mt. Šar-planina, 7. Mt. Bistra, 8. Mt. Jablanica, 9. Mt. Pelister.

$B \mathcal{G} H=$ Bosnia and Herzegovina; $M n=$ Montenengro; $S r=$ Serbia $;$ Ko $=$ Kosovo $; B u=$ Bulgaria $; M a=$ Macedonia; $G r=$ Grecee; $A l=$ Albania

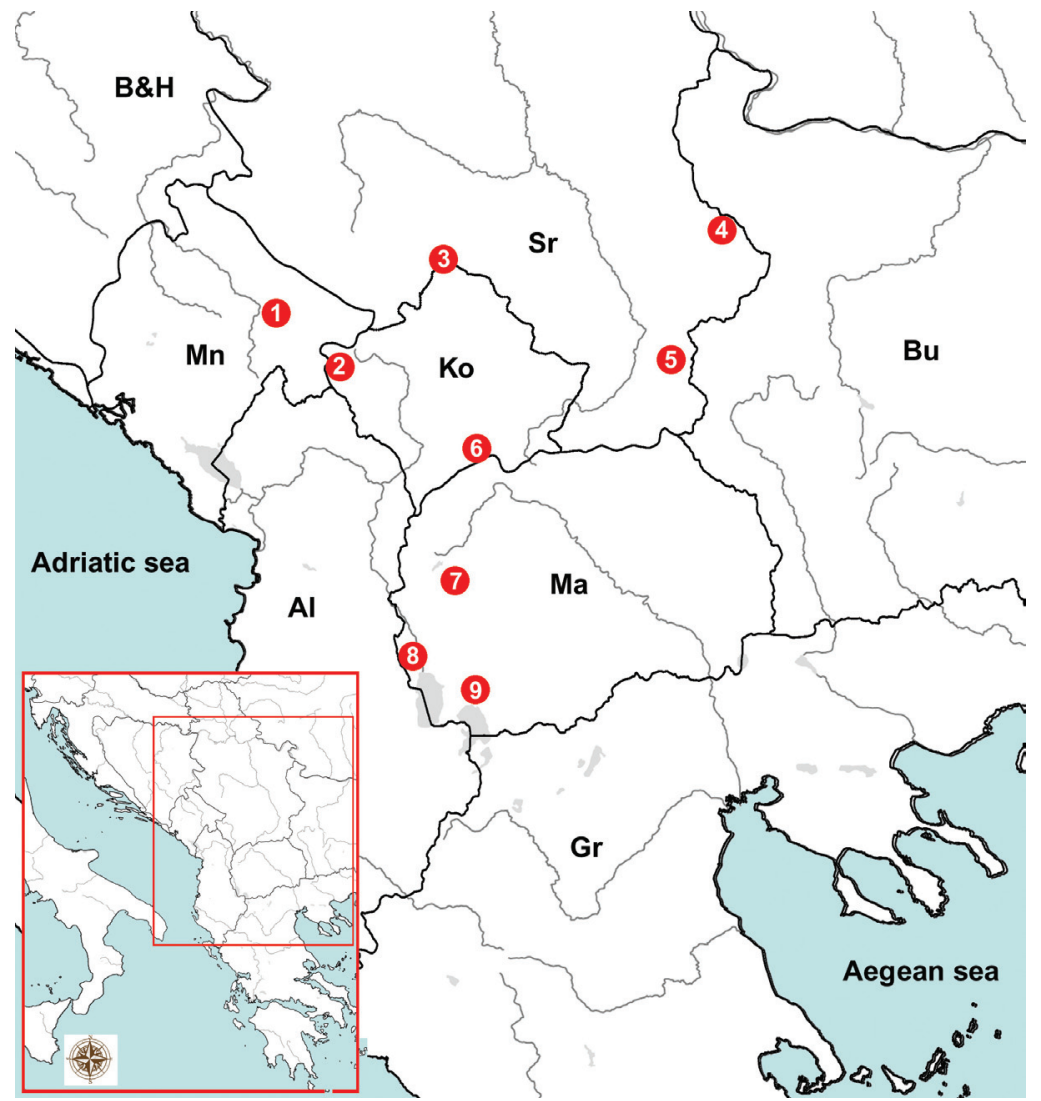

Distribution: The Rumicion balcanici is found in Montenegro (Mt Bjelasica -SE Dinarides), Serbia (Mt. Kopaonik - continental Dinarides, Mt. Stara planina, Vlasina Plateau and Krajište region - Balkan-Rodopaean system), Kosovo (Mt Prokletije - SE Dinarides, Mt. Šar-planina - Scardo-Pindian system), and Mecedonia (Mt. Jablanica - Scardo-Pindian system). The distribution area of Rumex balcanicus (Fig. 4) suggests that communities belonging to the alliance Rumicion balcanici could also be found in Bulgaria and Albania.

Syntaxonomy and nomenclature: The alliance Rumicion balcanici was proposed for the first time in (10). It was defined as a tall-herb vegetation developed on the gleyic and hydrogenic soils of the silicate massifs of the Prokletije phytogeographical sector (high-Dinaric province). R. Lakušić did not include any phytosociological table or single relevés in his paper, but only a short informal description of the alliance. In the same paper R. Lakušić stated that the Rumicion balcanici substituted the Scardo-Rhodopian Cirsion appendiculati in the SE-Dinarids. Thus, he indirectly included the Rumicion balcanici in the class Mulgedio-Aconitetea Hadač et Klika in Klika et Hadač 1944 (at that time known as Betulo-Adenostyletea). Three years later, in the "Prodromus of phytocoenosis of Montenegro"(29), the authors introduced the name Rumicetum balcanici Lakušić 65. The references "Lakušić 65", "Lakušić
1965 ", or "Lkšć 1965" recurred frequently in the Montenegro phytosociological literature. Nevertheless, no trace of this R. Lakušić 's 1965 manuscript has been found in the recent past, what is lead us to congecture that this, probably hand-written manuscript, was never published. As R. Lakušić (10) did not include any phytosociological table or single relevés usable as nomenclatural type in his paper, both the association Rumicetum balcanici Lakušić 1965 and the alliance Rumicion balcanici Lakušić 1973 are to be considered invalidly published (Art. 2b). Nonetheless, references to the name Rumicion balcanici, have been made in subsequent vegetation surveys concerning the Balkan area $(14,15,31,33,38,39)$.

In order to be phytogeographically consistent with the original description of the alliance Rumicion balcanici, the association Barbareo balcanae-Rumicetum balcanici V. Randjelović ex D. Lakušić, Ranđelović \& Di Pietro ass. nov. hoc loco (see below) has been selected in the present paper as the typus for the alliance $R u$ micion balcanici. This association was described for $\mathrm{Mt}$. Šutman (Šar-planina), which is located adjacent to Mt. Bjelasica (locus classicus of Rumicion balcanici) and in fact, these two montainous massifs show a high degree of floristic and vegetational similarities.

Within the Rumicion balcanici are to be included the natural meso-hygrophilous tall-herb communities char- 
acterized by a negligible anthropogenic impact. As a consequence we have provisionally classified this alliance in the Rumicetalia balcanici (or in the Adenostyletalia) and in the Mulgedio-Aconitetea. Other authors, however, included the Rumex balcanicus communities in other orders and classes. Blečić \& R. Lakušić (33) and Jovanović-Dunjić in Miš̌ć et al. (18) classified them in the Montio-Cardaminetea Br.-Bl. et Tx. 1943 while Petrović et al. (39) included the whole alliance Rumicion balcanici in the Rumicetalia alpini Mucina in Karner \& Mucina 1993. Indeed, the low frequency of tall-herbs, such as those belonging to the genera Mulgedium (= Lactuca), Aconitum, Ranunculus, Angelica, Doronicum or Cirsium, together with the high occurrence of medium-size species of the genus Cardamine (e.g. C. amara subsp. balcanica, C. acris, C. matthiolii) and mosses (Brachythecium rivulare, Plagiochilla asplenioides, Bryum pseudotriquetrum, Philonotis fontana, Sphagnum sp. div., etc.), could lend support to the inclusion of the Rumicion balcanici in the Montio-Cardaminetea. Further field investigations and large-scale comparative studies would be essential in order to establish the most appropriate syntaxonomical framework for this alliance.

The following associations are currently included in the Rumicion balcanici:

- Cardamino balcanicae-Rumicetum balcanici R. Jovanović 1971 ex D. Lakušić, Ranđelović \& Di Pietro ass. nov. hoc loco

- Barbareo balcanae-Rumicetum balcanici. V. Randjelović ex D. Lakušić, Ranđelović \& Di Pietro ass. nov. hoc loco

- Brachythecio rivularis-Rumicetum balcanici V. Randjelović ex D. Lakušić, Ranđelović \& Di Pietro ass. nov. hoc loco

$\Rightarrow$ Ranunculion serbici Lakušić et al. ex D. Lakušić, Ranđelović \& Di Pietro all. nov. hoc loco

(Rumicetalia balcanici (Adenostyletalia), Mulgedio-Aconitetea)

BasYonim: Ranunculion serbici Lakušić et al. 1987, [Art. 3o; 5]

NAME-GIVING SPECIES: Ranunculus serbicus

Typus: Ranunculetum serbici Lakušić et al. ex D. Lakušić, Ranđelović \& Di Pietro ass. nov. hoc loco

Diagnostic taxa: Ranunculus serbicus (trangr.)

Constant taxa: Agrostis capillaris, Caltha palustris, Cardamine matthioli, Centaurea jacea., Chaerophyllum hirsutum agg., Lactuca alpina, Deschampsia cespitosa, Epilobium hirsutum, Equisetum palustre, Filipendula ulmaria, Galium palustre, Lychnis flos-cuculi, Mentha longifolia, Myosotis scorpioides, Oenanthe banatica, Polygonum bistorta, Ranunculus aconitifolius, Ranunculus serbicus, Scirpus sylvaticus, Senecio nemorensis, Stellaria graminea, Veratrum lobelianum.
Diagnosis: Tall-herb vegetation of the flattened alluvial stream plains characterizing the spruce-fir-beech forests area in the C-Balkan peninsula (Fig. 5).

Distribution: On the basis of the phytosociological literature $(11,15,36,40)$ and our personal observations, the Ranunculion serbici occurs in Bosnia and Herzegovina (Leskovac near Han Pijesak), and in Serbia (Brzećka klisura gorge on Mt. Kopaonik, Vlasina Plateau, Donji Dušnik on Mt. Suva planina).

Syntaxonomy and nomenclature: The alliance Ranunculion serbici was invalidly published (Art. 3o; 5) in (11). It was based on the single association Ranunculetum serbici Lakušić R., Mišić Lj. \& Golić S. 1987 (nom. inval. Art. 3o; 5). The dominant species, Ranunculus serbicus, is a sub-endemic Balkan species with a few relic stations in the Calabria region in S-Italy (41). The Ranunculion serbici communities exhibit many geographical, ecological and floristic similarities to the tall-herb communities with dominance of Lactuca pancicii. Therefore, it is possible that in the future it could be considered a syntaxonomical synonym of the alliance Cicerbition pancicii.

The following associations are currently included in the Ranunculion serbici.

- Ranunculetum serbici Lakušić et al. ex D. Lakušić, Ranđelović \& Di Pietro ass. nov. hoc loco

- Equiseto polystachii-Ranunculetum serbici V. Randjelović ex D. Lakušić, Ranđelović \& Di Pietro ass. nov. hoc loco

$\Rightarrow$ Cicerbition pancicii Lakušić in Lakušić \& Redžić ex D. Lakušić, Ranđelović \& Di Pietro all. nov. hoc loco (Rumicetalia balcanici (Adenostyletalia), Mulgedio-Aconitetea)

Basyonim: Cicerbition pancicii Lakušić R., in Lakušić \& Redžić 1989, [Art. 3o; 5])

Name-giving SPecies: Lactuca pancicii (=Cicerbita pancicii)

Typus: Cirsio wettsteinii-Cicerbitetum pancicii Lakušić \& Redžić 1989 (12: 149)

Diagnostic taXa : Aconitum burnatii subsp. pentheri, Aconitum toxicum subsp. bosniacum, Angelica sylvestris, Aquilegia blecicii, Lactuca pancicii (transgr.), Cirsium boujartii subsp. wettsteinii (transgr.) Hesperis dinarica, Knautia sarajevensis, Lunaria telekiana, Lactuca aurea

Constant taxa: Aegopodium podagraria, Angelica sylvestris, Calamagrostis varia, Cardamine matthioli, Chaerophyllum hirsutum agg., Lactuca pancicii, Cirsium boujartii subsp. wettsteinii, Clematis recta, Equisetum palustre., Mentha longifolia, Molinia caerulea, Petasites hybridus, Petasites kablikianus, Prunella vulgaris, Ranunculus repens, Rubus caesius, Thalictrum simplex 


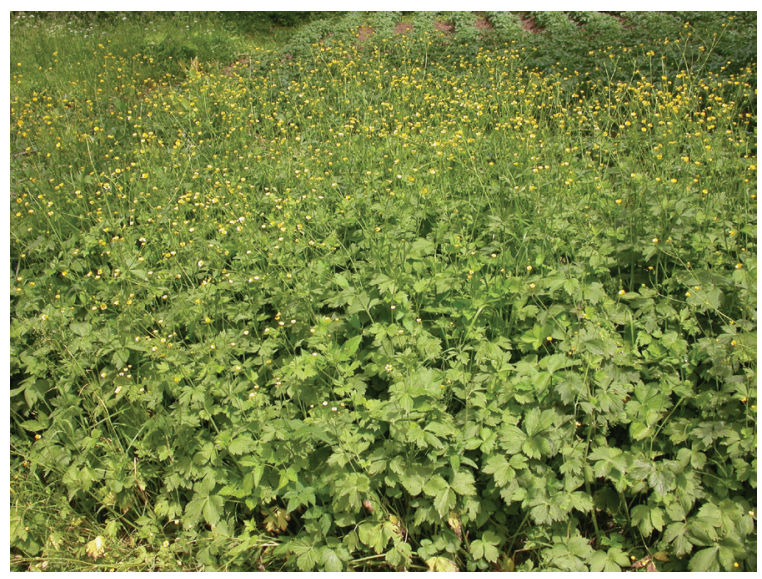

Fig. 5 - Community with dominance of Ranunculus serbicus, All.: Ranunculion serbici. Serbia, Mt. Suva planina, Donji Dušnik, c. 600 m, limestone (photo: D. Lakušić 31.05.2006).

Diagnosis: Tall-herb communities developed within the humid mild limestone slopes (slope: $15-30^{\circ}$ ) ranging between the submontane and the subalpine belts, on hydrogenic calkomelanosol soils. The total cover ranges between 95 and $100 \%$, while the height of the dominant herb-layer between 150 and $200 \mathrm{~cm}$ (Fig. 6). The Cicerbition pancicii communities are almost always natural vegetation types, sometimes playing the role of potential vegetation, characterized by a negligible anthropogenic impact.

DistribUTION: In Montenegro this alliance occurs in the Canyon of the Tara river (Neviđeno, mouth of river Sušica, Bijele vode, Lazin kamen, Izvori near Sušićka pećina, Curovac), and Ropojana valley in the Mt. Prokletije. In Bosnia-Herzegovina it occurs in the Canyon of the river Sutjeska (personal field observation). On the basis of the whole distribution of Lactuca pancicii it is hypothesizable that the alliance Cicerbition pancicii also occurs in Serbia, Albania and Macedonia.

Syntaxonomy and nomenclature: The alliance Cicerbition pancicii was proposed in (11) under the phantom name of Mulgedion pancicii Lakušić. Two years later R. Lakušić \& Redžić (12) introduced the new name Cicerbition pancicii Lakušić (nomen novum), and included in it four new tall-herb associations which were described for the Tara canyon in Montenegro (Cirsio-Cicerbitetum pancicii, Cicerbito-Petasitetum hybridi, Molinio-Adenophoretum lilifoliae, Chaerophyllo-Cirsietum wettsteinii). The phytosociological relevés of these associations were arranged in a phytosociological table (Tab. 4 page 150) composed of 5 relevés. The first two relevés were included in the $\mathrm{Mo}$ linio-Adenophoretum while the other three relevés were classified as belonging to Cirsio-Cicerbidetum pancici, Cicerbito-Petasitetum and Chaerophyllo-Cirsietum re-

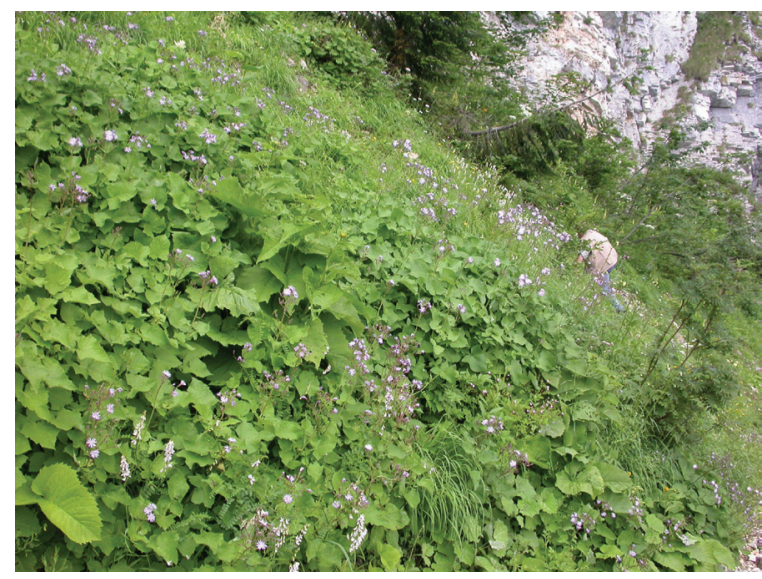

Fig. 6 - Community with dominance of Lactuca pancicii, All. : Cicerbition pancicii. Montenegro, Mt. Durmitor, Ćurovac, c. 1400 m, limestone (photo: D. Lakusici 16.07.2006).

spectively. These latter three associations were therefore validly published by virtue of their single relevès, which automatically played the role of nomenclatural types of each of the three associations. In contrast, the Molinio-Adenophoretum has to be considered as invalidly described, due to the occurrence of two relevés usable as nomenclatural type (Art. 3o; 5). The alliance Cicerbition pancicii Lakušić \& Redžić 1989 is thus invalid because there are three valid associations included in the original diagnosis of this alliance and none of these was designated as typus (Art. 3; 5). In the present paper the alliance Cicerbition pancicii is validated through the designation of the Cirsio-Cicerbitetum pancicii Lakušić \& Redžić 1989 as lectotypus.

The following associations are currently included in the Cicerbition pancicii:

- Chaerophyllo hisuti-Cirsietum wettsteinii Lakušić \& Redžić 1989

- Cicerbito pancicii-Petasitetum hybridi Lakušić \& Redžić 1989

- Cirsio wettsteinii-Cicerbitetum pancicii Lakušić \& Redžić 1989

- Molinio arundinaceae-Adenophoretum lilifoliae Lakušić \& Redžić ex D. Lakušić, Ranđelović \& Di Pietro ass. nov. hoc loco

$\Rightarrow$ Petasition doerfleri Lakušić ex D. Lakušić, Ranđelović \& Di Pietro all. nov. hoc loco

(Thlaspietea rotundifolii, Thlaspietalia rotundifolii)

Basyonim: Petasition doerfleri Lakušić 1968 [Art. 2b]

Name-giving sPecies: Petasites doerfleri

Typus: Valeriano bertiscei-Petasitetum doerfleri D. Lakušić \& Di Pietro ass. nova hoc. loco 
Diagnostic taxa: Adenostyles alliariae, Geum bulgaricum, Heracleum sphondylium subsp. orsinii, Petasites doerfleri, Potentilla montenegrina. Wulfenia carinthiaca (=W. blecicii)

Constant taxa: Arabis alpina, Cardamine glauca, Cystopteris montana, Doronicum columnae, Ranunculus breyninus (=Ranunculus oreophilus) Saxifraga rotundifolia s.l. Senecio rupestris.

Diagnosis: Vegetation occurring within the humid and stable coarse-grained calcareous screes and in the boulder-strewn fields of the upper-montane and subalpine belts of the SE Dinarides. The Petasition doerfleri vegetation is characterized by a mixture of small creeping plants and tall-herbs. It is developed on the flat or moderately steep slopes $\left(0-30^{\circ}\right)$ characterized by initial calkomelanosol soils. The total cover of the vegetation is about $50-80 \%$. The height of the dominant herb-layer may (in rare cases) reach $100 \mathrm{~cm}$. The majority of the communities classified in the Petasition doerfleri represents a typical form of natural potential vegetation. (Fig. 7).

Distribution: Mts Prokletije in Montenegro and Albania. The information about the occurrence of the Petasition doerfleri communities in the Herzegovina are to be confirmed. Physiognomically similar communities dominated by the tall-herbs Adenostyles alliariae and Heracleum orsinii were recorded in Montenegro within the subalpine humid stable screes of Mt. Durmitor and Mts Komovi.

Syntaxonomy and nomenclature: The alliance Petasition doerfleri was originally described in (9). This alliance included the plant communities with dominance of tall herbs developed on humid stable screes. Because the dominant tall-herbs occurring in the Petasition doerfleri communities exhibited high cover values (up to 40-60\%), this alliance was originally classified in the Adenostyletalia Br-Bl. 1931 and in the Mulgedio-Aconitetea (formerly Betulo-Adenostyletea). R. Lakušić (9) included in the Petasition doerfleri the following new associations: Adenostylo-Petasitetum doerfleri, Geetum bulgarici, Linario-Daphnetum oleoides and Doronico-Wulfenietum blecicii. Only the DoronicoWulfenietum blecicii, out of these four associations, was described through a complete phytosociological table. The other three associations were simply arranged in a summarizing synoptic table reporting only the characteristic species of each association (three species per association). As a consequence, these three associations are to be considered invalid (art. 2b, 7). The DoronicoWulfenietum is the only validly described association occurring in the original diagnosis of the Petasition doerfleri. It is, therefore, the only element usable as nomenclatural type for the alliance. This role, however, cannot be played by the Doronico-Wulfenietum blecicii since the species Petasites doerfleri does not occur in the phytosociological table of the association.
Owing to the lack of Petasites doerfleri in the only validly published association of the alliance, the name Petasition doerfleri Lakušić 1968 is to be considered invalid (Art. 3f). The lack of knowledge about this nomenclatural shortcoming led to the name Petasition doerfleri being subsequently used in many important national and international vegetation surveys $(31,33$, 35, 39).

As already mentioned, the association Doronico-Wulfenietum blecicii is validly published and therefore suitable to be used as nomenclatural type for an eventual new alliance having the same diagnosis as the Petasition doerfleri, but bearing a different name. Nevertheless, we have opted to validate the name Petasition doerfleri Lakušić 1968 all nov. hoc loco, designating the holotypus in the association Valeriano bertisceiPetasitetum doerfleri D. Lakušić \& Di Pietro ass. nov. hoc loco (see below) which exhibits its locus classicus in the Mt. Maja Jezerces in the Prokletije Mts.(NEAlbania). Two main reasons led us to opt for this solution. First, Petasites doerfleri is endemic to the SE-Dinaric humid and stable calcareous screes, so that it is perfectly suitable for representing, both geographically and ecologically, the vegetation in issue (Fig. 7). Second, the possible choice of Doronico-Wulfenietum blecicii would have entailed the abandonment of a wellknown name (Petasition doerfleri), owing to the aforementioned lack of the name-giving species (Petasites doerfleri) in the original phytosociological table of the Doronico-Wulfenietum. This would have meant introducing a new name, and therefore adding confusion to an already intricate nomenclatural issue.

From a coenological point of view the majority of the characteristic and constant species of the alliance Petasition doerfleri exhibit ecological features which are closer to those of the scree habitats than to those of the tall-herb ones. In fact, with the exception of Adenostyles alliariae and Lactuca pancicii (both occurring in the typical tall-herb vegetation, too), all the other species reported in the phytosociological table of the association Valeriano-Petasitetum (Table 1) are known as typical scree species. For this reason, and in contrast to the diagnosis made in (9), the alliance Petasition doerfler is here classified in the Thlaspietea rotundifolii.

The following two associations are to be considered as included in the Petasition doerfleri at present:

- Doronico-Wulfenietum blecicii Lakušić 1968

- Valeriano bertiscei-Petasitetum doerfleri D. Lakušić \&

Di Pietro ass. nova hoc loco

It was not possible for us to formalize the validation of the Geetum bulgarici and the Linario-Daphnetum (included by R. Lakušić (9) in the original diagnosis of the Petasition doerfleri), since at present there are no published phytosociological tables or single relevés from which to select a possible nomenclatural type. 


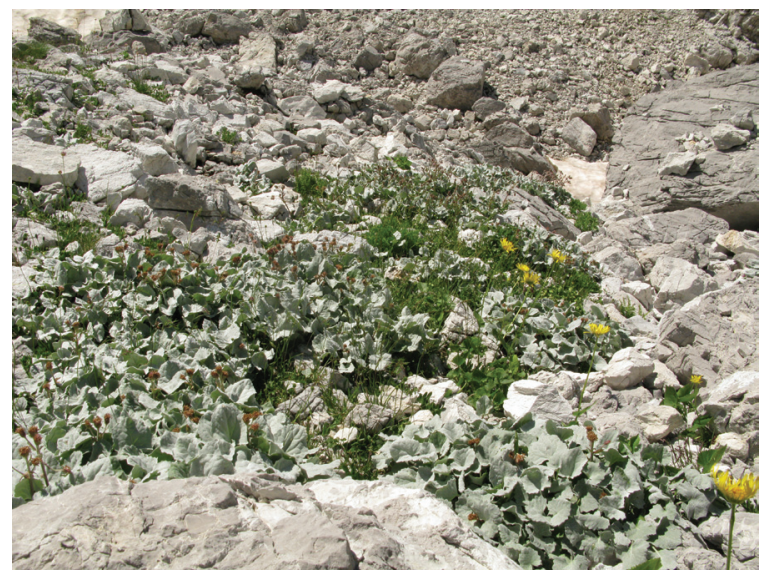

Fig. 7 - Ass. Valeriano bertiscei-Petasitetum doerfleri. All. Petasition doerfleri, Albania, Mt. Prokletije, Maja e Jezerces, 2150 $m$, limestone (photo: D. Lakušic 27.07.2011).

\section{Validation of some association names originally included in the order Rumicetalia balcanici}

Chaerophyllo hirsuti-Cirsietum oleracei Ranđelović ex D. Lakušić, Ranđelović \& Di Pietro ass. nov. hoc loco

(Cirsion appendiculati, Rumicetalia balcanici (Adenostyletalia), Mulgedio-Aconitetea)

[Orig. Chaerophyllo-Cirsietum oleracei Ranđelović in Ranđelović \& Zlatković 2010, (Art. 30, 5)]

- Type relevé (Typus hoc loco designatus): Ranđelović \& Zlatković 2010, p. 286, Tab. 30, rel. 2

- Name-giving species: Chaerophyllum hirsutum, Cirsium oleraceum

- Diagnostic taxa: Cirsim oleraceum, Chaerophyllum hirsutum

- Constant taxa: Mentha x verticillata, Filipendula ulmaria, Alchemilla gracilis, Potentilla erecta, Myosotis scorpioides, Galium palustre

Veratro lobeliani-Cirsietum helenioidis Ranđelović ex D. Lakušić, Ranđelović \& Di Pietro ass. nov. hoc loco

(Cirsion appendiculati, Rumicetalia balcanici (Adenostyletalia), Mulgedio-Aconitetea)

[Orig. Cirsietum helenioidei Ranđelović in Ranđelović \& Zlatković 2010 (Art. 30, 5)]

- Type relevé (Typus hoc loco designatus): Ranđelović \& Zlatković 2010, p. 283, Tab. 29, rel. 4

- Name-giving species: Veratrum lobelianum, Cirsium belenioides

- Diagnostic taxa: Cirsium helenioides

- Constant taxa: Veratrum lobelianum, Filipendula ulmaria, Agrostis canina, Potentilla erecta
Trollio europaei-Geetum rhodopaei Ranđelović ex D. Lakušić, Ranđelović \& Di Pietro ass. nov. hoc loco

(Geion coccinei, Rumicetalia balcanici (Adenostyletalia), Mulgedio-Aconitetea)

[Orig. Trollio-Geetum rhodopaei Ranđelović in Ranđelović \& Zlatković 2010, (Art. 30, 5)]

- Type relevé: (Typus hoc loco designatus): Ranđelović \& Zlatković 2010, p. 269, Tab. 26, rel. 10.

- Name-giving species: Geum rhodopeum, Trollius europaeus

- Diagnostic taxa: Geum rhodopeum, Trollius europaeus, Dactylorhyza cordigera

- Constant taxa: Veratrum lobelianum, Plagiomnium elatum, Juncus effusus, Potentilla erecta, Myosotis scorpioides.

Geo rivali-Filipenduletum ulmariae V. Ranđelović in Ranđelović \& Zlatkovic ex D. Lakušić, Ranđelović \& Di Pietro ass. nov. hoc loco

(Geion coccinei, Rumicetalia balcanici (Adenostyletalia), Mulgedio-Aconitetea)

[Orig.:Geo-Filipenduletum ulmariae V. Ranđelović \& Zlatković 2010: (nom. inval. Art. 3o, 5)]

- Type relevé (Typus hoc loco designatus): Ranđelović \& Zlatković 2010, p. 278, Tab. 28, rel. 9.

- Name-giving species: Geum rivale, Filipendula ulmaria

- Diagnostic taxa: Geum rivale, Geum rhodopeum, Geum rhodopeum $x$ rivale, Filipendula ulmaria

- Constant taxa: Deschampsia caespitosa, Veratrum lobelianum, Equisetum palustre, Lathyrus pratensis, Scirpus sylvaticus, Myosotis scorpioides, Carex rostrata, Succisa pratensis, Carex nigra, Potentilla erecta.

Cardamino balcanicae-Rumicetum balcanici R. Jovanović ex D. Lakušić, Ranđelović \& Di Pietro ass. nov. hoc loco

(Rumicion balcanici, Rumicetalia balcanici (Adenostyletalia), Mulgedio-Aconitetea)

[Orig.: Cardamino-Rumici-Calthetum R. Jov. 1971 (Art. 2) ]

[Synonyms: = Cardamino-Rumici-Calthetum R. Jov. 1971 in Jovanović-Dunjić 1971 (nomen nudum); Cardamino-Rumici-Calthetum R. Jov. ex Mišić et al. 1978 (nom. Illeg. Art. 34c); Cardamino balcanicae-Rumicetum balcanici Ranđelović in Lakušić et al 2005: 121 (nom. inval. Art. 3; 5]

- Type relevé (Typus hoc loco designatus): Mišić et al. 1978, p. 346, Tab. 64, rel. 4.

- Name-giving species: Cardamine amara subsp. balcanica, Rumex balcanicus 
Table 1. Valeriano bertiscei-Petasitetum doerfleri D. Lakušic \& Di Pietro ass. nova hoc. loco Sampled by: D. Lakusicic (27.7.2011). The phytosociological relevés of the table were performed according to Braun-Blanquet (45)

\begin{tabular}{|c|c|c|c|c|c|}
\hline \multirow{2}{*}{\begin{tabular}{|l} 
Locality \\
Latitude (N)
\end{tabular}} & \multicolumn{5}{|c|}{ Albania, Maja Jezercë } \\
\hline & 42.450252 & 42.450252 & 42.450252 & 42.449354 & 42.449354 \\
\hline Longitude (E) & 19.804490 & 19.804490 & 19.804490 & 19.806983 & 19.806983 \\
\hline Altitude (m) & 2100 & 2100 & 2100 & 2150 & 2150 \\
\hline Cover $\left(^{\circ}\right)$ & 50 & 60 & 60 & 80 & 70 \\
\hline Slope (\%) & 20 & 10 & 10 & 5 & 5 \\
\hline Aspect & SW & SW & SW & SW & SW \\
\hline Relevé area $\left(\mathrm{m}^{2}\right)$ & 16 & 8 & 2 & 10 & 6 \\
\hline Rel.no. & 1 & 2 & 3 & $4^{\text {(typus) }}$ & 5 \\
\hline \multicolumn{6}{|l|}{ Char. of association and alliance } \\
\hline Petasites doerfleri & 3.4 & 3.4 & 3.4 & 4.4 & 3.4 \\
\hline Valeriana bertiscea & 1.1 & 1.1 & + & 1.1 & 1.3 \\
\hline Heracleum sphondylium subsp. orsinii & - & - & - & - & 1.1 \\
\hline \multicolumn{6}{|l|}{ Char. of order and class } \\
\hline Adenostyles alliariae & - & - & - & - & 1.1 \\
\hline Doronicum columnae & - & - & + & 1.2 & 1.1 \\
\hline Leontodon montanus & 1.1 & 1.1 & + & 1.1 & - \\
\hline Salix serpillifolia & + & 1.2 & 1.3 & - & - \\
\hline Ranunculus crenatus & 1.1 & 1.1 & 1.1 & - & - \\
\hline Arabis alpina & - & - & - & - & 1.1 \\
\hline \multicolumn{6}{|l|}{ Other species } \\
\hline Poa alpina var. vivipara & 1.1 & 1.1 & 1.1 & 1.2 & 1.1 \\
\hline Cystopteris montana & - & + & - & 1.1 & - \\
\hline Taraxacum sp. & - & - & + & - & - \\
\hline Armeria alpina & 1.1 & + & - & - & - \\
\hline Senecio rupestris & - & - & - & - & + \\
\hline
\end{tabular}

- Diagnostic taxa: Cardamine amara subsp. balcanica, Rumex balcanicus

- Constant taxa: Caltha cornuta, Crepis paludosa, Myosotis palustris, Epilobium palustre, Poa palustris

Note: In the original paper of Jovanović-Dunjic (17) the epithet "Cardamino" occurring in the name of the association "Cardamino-Rumici-Calthetum" referred to the taxon Cardamine amara. The community was described for the Mt. Stara planina where only the sub-species $C$. amara subsp. balcanica Marhold, Ančev \& Kit Tan occurs (42). The Cardamino balcanicae-Rumicetum balcanici occurs in C-Serbia on the Mt. Kopaonik, too (personal field observation).

Barbareo balcanae-Rumicetum balcanici V. Randjelović ex D. Lakušić, Ranđelović \& Di Pietro ass. nov. hoc loco

(Rumicion balcanici, Rumicetalia balcanici (Adenostyletalia), Mulgedio-Aconitetea)
[Orig. Barbareo-Rumicetum balcanici prov. V. Randjelović 1998 in Ranđelović et al. 1998: 381 nom. nud. (Art. 2, 4a)]

- Type relevé (see below)

- Name-giving species: Barbarea balcana, Rumex balcanicus

- Diagnostic taxa (based on two releves made in locus classicus): Rumex balcanicus, Barbarea balcana, Cardamine matthioli, Trifolium badium, Willemetia stipitata, Pedicularis verticillata, Silene asterias, Saxifraga rotundifolia

- Type relevé (Typus hoc loco designatus): Serbia (Kosovo), Šar-planina Mt., Šutman, between Tija Voda and Belojezerski Rid, altitude $2180 \mathrm{~m}$, relevé area $25 \mathrm{~m}^{2}$, slope 0 , cover $100 \%$, silicate, sampled by Ranđelović using the 7-degree Braun-Blanquet scale, 01.08.1997. 
Plant list: (herb layer): Rumex balcanicus 5, Barbarea balcana 1, Veratrum lobelianum 1, Caltha palustris 1, Cardamine matthioli 1, Pedicularis verticillata $1, P h-$ leum alpinum +, Saxifraga rotundifolia +, Trifolium badium +, Willemetia stipitata +.

Note: The Barbareo balcanae-Rumicetum balcanici is developed on siliceous substrates of the spring peat-bogs occurring on Mt. Šar-planina. The association is mainly composed of medium-size herbaceous hygrophytic plants.

Brachythecio rivularis-Rumicetum balcanici D. Lakušić, Ranđelović \& Di Pietro ass. nov. hoc loco

(Rumicion balcanici, Rumicetalia balcanici (Adenostyletalia), Mulgedio-Aconitetea)

[Orig. Rumicetum balcanici (Lakušić 1965) Ranđelović 2001 (Art. 1)]

- Type relevé (Typus hoc loco designatus): Ranđelović \& Zlatković 2010, p. 266, Tab. 25, rel. 2

- Name-giving species: Brachythecium rivulare, Rumex balcanicus

- Diagnostic taxa: Rumex balcanicus

- Constant taxa: Plagiochilla asplenioides, Veratrum lobelianum, Chaerophyllum hirsutum, Brachythecium rivulare, Carex nigra, Caltha palustris, Ranunculus acris, Mentha longifolia, Potentilla erecta, Myosotis scorpioides

Note: In his Phd thesis (14), published later as Monograph "Flora and vegetation of Vlasina Plateau" (15), Ranđelović provided an analytical table of a community dominated by Rumex balcanicus which was composed of 5 relevés. According to the author this community (from Vlasina Plateau in SE Serbia) exhibited strong ecological similarities with the Rumicetum balcanici invalidly described by R. Lakušić (10) for the Mt. Bjelasica in Montenegro. Accordingly he proposed the new name Rumicetum balcanici (Lakušić 1965) Ranđelović 2001 for the Vlasina Plateau communities. In (14) V. Randjelović published many syntaxa bearing the authorship reference "V. Randj. 2001". The year "2001" refers to the first version of the $\mathrm{PhD}$ manuscript which was concluded in 2001, but formally published in 2002. Just nine copies of this $\mathrm{PhD}$ thesis were printed, so the new syntaxa published in it are to be considered invalid (Art. 1). Subsequently, the syntaxonomical results of this $\mathrm{PhD}$ thesis (14) were made available to the international phytosociological community when it was published as a monograph entitled "Flora and vegetation of Vlasina Plateau" (15), where the 5 relevés of the association Rumicetum balcanici (Lakušić 1965) Ranđelović 2001 were proposed again. Only six species (Rumex balcanicus, Caltha palustris subsp. laeta, Carex flava, Carex nigra, Filipendula ulmaria and Veratrum lobelianum), out of the fifty-four species obtained summing the species occurring in the Rumex balcanicus communities sampled by R. Lakušić on Mt Bjelasica (10) with those sampled by V. Randjelović on the Vlasina Plateau (15), were found to occur simultaneously in both the communities. This strong floristic difference is probably due to the fact that Mt Bjelasica and Vlasina Plateau belong to two geographically separated montainous ranges (Dinarids and Rhodopean Mts.), each of which fall within a different phytogeographical unit $(8,43)$. As a consequence, we propose here to distinguish the Rumex balcanicus communities found in these two areas in the form of two different associations. The communities of the Vlasina Plateau are here included in the new association Brachythecio rivularis-Rumicetum balcanici ass. nov. hoc loco. The communities of Mt. Bjelasica are provisionally named with the only nomenclatural reference available at present, that is, the invalid name Rumicetum balcanici Lakušić (1965) 1973. In fact, R. Lakušić (10) did not provide any phytosociological table or single relevé usable for a possible validation or for the proposal of a new name.

Molinio arundinaceae-Adenophoretum lilifoliae Lakušić \& Redžić ex D. Lakušić, Ranđelović \& Di Pietro ass. nov. hoc loco

(Cicerbition pancicii, Rumicetalia balcanici (Adenostyletalia), Mulgedio-Aconitetea)

[Orig. Molinio-Adenophoretum lilifoliae Lakušić \& Redžić 1988, (Art. 3o, 5)]

- Type relevé (Typus hoc loco designatus): Lakušić \& Redžić 1989, p. 150, Tab. 4, rel. 2.

- Name-giving species: Molinia arundinacea, Adenophora lilifolia

- Diagnostic taxa: Molinia arundinacea, Adenophora lilifolia, Lactuca pancicii, Clematis recta.

- Constant taxa: Calamagrostis varia, Thalictrum simplex, Prunella vulgaris.

Ranunculetum serbici Lakušić et al. ex D. Lakušić, Ranđelović \& Di Pietro ass. nov. hoc loco

(Ranunculion serbici, Rumicetalia balcanici (Adenostyletalia), Mulgedio-Aconitetea)

[Orig. Ranunculetum serbici Lakušić R., Mišić Lj. \& Golić S. 1987, (Art. 3o, 5)]

- Type relevé (Typus hoc loco designatus): Lakušić et al, 1987, Tab. 1, rel. 5.

- Name-giving species: Ranunculus serbicus

- Diagnostic taxa: Ranunculus serbicus

- Constant taxa: Myosotis palustris, Cardamine matthiolii, Filipendula ulmaria, Mentha longifolia, Ranunculus aconitifolius

Equiseto polystachii-Ranunculetum serbici V. Randjelović in Ranđelović \& Zlatković 2010 ex D. Lakušić, Ranđelović \& Di Pietro ass. nov. hoc loco 
(Ranunculion serbici, Rumicetalia balcanici (Adenostyletalia), Mulgedio-Aconitetea)

[Orig. Polystachio-Ranunculetum serbicae Ranđelović in Ranđelović \& Zlatković 2010 (Art. 3o, 5)]

- Type relevé (Typus hoc loco designatus): Ranđelović \& Zlatković 2010, p 275, Tab. 27, rel. 1.

- Name-giving species: Ranunculus serbicus, Equisetum palustris var. polystachis

- Diagnostic taxa: Ranunculus serbicus, Equisetum palustris var. polystachis

- Constant taxa: Chaerophyllum hirsutum, Epilobium hirsutum var. villosum, Fiipendula ulmaria, Veratrum lobelianum, Equistum palustre, Mentha longifolia, Myosotis scorpioides, Caltha palustris, Juncus effusus, Oenanthe banatica.

\section{A new association and a lectotypification in the alliance Petasition doerfleri}

\section{Doronico-Wulfenietum blecicii Lakušić 1968}

(Petasition doerfleri, Thlaspietalia rotundifolii (prov.), Thlaspietea rotundifolii)

- Type relevé (lectotypus hoc loco designatus): Lakušić 1968, p 39, Tab. 27, rel. 3).

- Name-giving species: Doronicum columnae, Wulfenia carinthiaca

- Diagnostic taxa: Doronicum columnae. Wulfenia carinthiaca, Ranunculus breyininus

- Constant taxa: Adenostyles alliariae, Sedum magellense, Arabis alpina, Cardamine glauca, Gymnocarpium robertianum.

Note: A recent paper on the evolution, phylogeny and systematics of the genus Wulfenia, (44) has shown that the split of the W. blecicii-W. carinthiaca aggregate into two geographically distinct taxa distributed in the SEAlps (W. carinthiaca s.str.) and SE-Dinarids (W. blecicii) is not supported by molecular or morphological evidence. According to this paper (44) only one taxon, W. carinthiaca, is to be maintained as a good species and W. blecicii is to be included in W. carinthiaca.

Valeriano bertiscei-Petasitetum doerfleri D. Lakušić \& Di Pietro ass. nova hoc. loco

(Petasition doerfleri, Thlaspietalia rotundifolii (prov.), Thlaspietea rotundifolii)

- Type relevé (Holotypus hoc loco designatus): Table 1, rel. 4. (present paper)

- Name-giving species: Valeriana bertiscea, Petasites doerfleri

- Diagnostic taxa: Petasites doerfleri, Valeriana bertiscea
- Constant taxa: Petasites doerfleri, Valeriana bertiscea, Poa alpina, Leontodon montanus, Doronicum columnae

Note: The Valeriano bertiscei-Petasitetum doerfleri is developed within the cold and humid stable coarsegrained calcareous screes and boulder-strewn fields of the subalpine belt of the Prokletije Mts. (Fig. 7). It occurs on mildslopes $\left(5-20^{\circ}\right)$ on the initial calkomelanosol soils. The total vegetation cover ranges between 50 and $80 \%$. The association is floristically poor with the cryophytic, tall-herb Petasites doerfleri playing the role of dominant species. The rest of the specific component is composed of small-size creeping or tufted hemicryptophytes and hameaphytes.

\section{ACKNOWLEDGEMENTS}

We acknowledge the financial support provided by the Serbian Ministry of Science and Technological Development (project no. 173030), and Vlado Matevski (Skopje) and Gordana Tomović (Belgrade) who provide us informations, literature and photo documentation about the occurrence of some syntaxa in Macedonia and Greece and to J.P. Theurillat for his nomenclatural help. Thanks to friend Jim Mc Manus for his help revising the english language of the paper.

\section{REFERENCES}

1. ADAMOVIĆ L 1909 Die Vegetationsverhältinisse der Balkanländer (Mösische Länder). Die Vegetation der Erde 11, Leizig.

2. HORVAT I 1935 Istraživane vegetacije planina Vardarske banovine. Ljetopis Jugoslovenske akademije znanosti i umjetnosti 47: 142-160.

3. HORVAT I 1936 Istraživanje vegetacije planina Vardarske banovine, 2. Ljetopis Jugoslovenske akademije znanosti i umjetnosti 48: 211-227.

4. HORVAT I 1949 Nauka o biljnim zajednicama, Nakladni zavod Hrvatske. Zagreb.

5. HORVAT I 1960 Planinska vegetacija Makedonije u svijetlu suvremenih istraživanja. Acta Musei macedonici scientarum naturalium 6(8): 1-34.

6. HORVAT I 1962 Vegetacija planina zapadne Hrvatske, sa 4 karte biljnih zajednica sekcije Sušak. Prirodoslovna istraživanja JAZU 30. Acta Biologica 2: 1-179.

7. HORVAT I, PAWLOWSKI B, WALAS J 1937 Phytosoziologishe Studien über die Hochgebirgsvegetation der Rila Planina in Bulgarien. Bulletin Académie Polonaise Science Lettres, Classe Sciences Mathématique et Naturelle - Série B: Science Naturelle (1): 159-189.

8. HORVAT I, GLAVAČ V, ELLENBERG H 1974 Vegetation Südosteuropas. Gustav Fisher Verlag, Stuttgart.

9. LAKUŠIĆ R 1968 Planinska vegetacija jugoistočnih Dinarida. Glas. Rep. Zavoda Zašt. Prir. Prirod. Muz. (Titograd) 1: 9-75.

10. LAKUŠIĆ R 1973 Rumex balcanicus Rech. fil. novi tercijerni relikt u florui Crne Gore. Glas. Rep. Zavoda Zašt. Prir. Prirod. Muz. (Titograd) 5: 29-32.

11. LAKUŠIĆ R, MIŠIĆ L J, GOLIĆ S 1987 Ranunculetum serbici Lakušić, Mišić \& Golić Assoc. nova. Bilten Društva ekologa BiH. Ekološke monografije 4: 117-121. 
12. LAKUŠIĆ R, REDŽIĆ S 1989 Flora i vegetacija vaskularnih biljaka u refugijalno-reliktnim ekosistemima kanjona rijeke Drine i njenih pritoka. The flora and the vegetation of vascular plants in refugial-relict ecosystems in the canyon of the river Drina and its tributaries. Crnogorska akademija nauka i umjetnosti, Glasnik Odjeljenja Prirodnih Nauka, 7: 107-206, Titograd.

13. RANDELOVIĆ V, ZLATKOVIĆ B, AMIDŽIĆ L 1998. Flora i vegetacija visokoplaninskih tresava Šar planine. Zaštita prirode 50: 377-387.

14. RANDELOVIĆ V 2002 Flora i vegetacija Vlasinske visoravni. Doktorska disertacija, Univerzitet u Beogradu, Biološki fakultet, Beograd.

15. RANDELOVIĆ V, ZLATKOVIĆ B 2010 Flora i vegetacija Vlasinske visoravni. Prirodno-matematički fakultet, Niš, pp. 448.

16. RUDSKI I 1938 Biljne zajednice na visokim planinama južne Srbije. Šumarski list 12: 611-623.

17. JOVANOVIĆ-DUNJIĆ R 1971 Ispitivanja strukture i ekoloških uslova fitocenoza u jednom mozaikkompleksu na tresavama Stare planine. Glasnik Instituta za botaniku i Botaničke bašte Univerziteta u Beogradu 6(1-4): 91-106.

18. MIŠIĆ V, JOVANOVIĆ-DUNJIĆ R, POPOVIĆ M, BORISAVLJEVIĆ L J, ANTIĆ M, DINIĆ A. DANON J, BLAŽENČIĆČ 1978: Biljne zajednice i staništa Stare planine. Srpska akademija nauka i umetnosti, Posebna izdanja 511, Odeljenje prirodno-matematičkih nauka 49: 1-389, Beograd.

19. MICEVSKI K 1994 Visokoplaninska vegetacija na planinata Bistra. Makedonska akademija na naukite i umetnostite, Bistra 3, Skopje.

20. VUKOJIČIĆ S, LAKUŠIĆ D 1994 Vegetacija sipara i visokih zeleni planine Mučanj (JZ Srbija). Glasnik Instituta za botaniku i Botaničke bašte Univerziteta u Beogradu 28: 221-235.

21. ROUSSAKOVA V 2000 Vegetation alpine et sous alpine superieure de la montagne de Rila (Bulgarie). Braun-Blanquetia 25: 3-132.

22. SURINA B 2005 The association Doronico austriaci-Adenostyletum alliariae Horvat ex Horvat et al. 1974 on the Mt. Snežnik (Liburnian karst, NW Dinaric Mts.). Razprave 4. Razreda SAZU 46(2): $145-160$.

23. ČARNI A, MATEVSKI V 2010 Vegetation along mountain streams in the southern part of the Republic of Macedonia. BraunBlanquetia 46: 157-170.

24. QUEZEL P. 1964 Végétation des hautes montagnes de la Grece meridionale. Vegetatio 12(5-6): 289-386. http://dx.doi. org/10.1007/BF03026056

25. QUEZEL P. 1967 La végétation des hautes sommets du Pinde et de l'Olympe de Thessalie. Vegetatio 14(1-4): 127-228. http:// dx.doi.org/10.1007/BF02639846

26. QUEZEL P. 1969 La végétation du massif de Bela Voda (Macédonia Nord-Occidentale). Biologia Gallo-Hellenica 2(2): 93-112.

27. WEBER H E, MORAVEC J, THEURILLAT J P 2000 International code of phytosociological nomenclature. Journal of Vegetation Science 11: 739-768.

28. EURO+MED PLANTBASE 2006 - the information resource for Euro-mediterranean plant diversity. Published on the Internet http://ww2.bgbm.org/EuroPlusMed/ [30/04/2014].

29. TUTIN T G, HEYWOOD V H, BURGES N A, MOORE D M, VALENTINE D H, WALTERS S M, WEBB D A, (ed.) 19641980 Flora Europaea. Voll. 1-5. Cambridge University Press, Cambridge.

30. MUCINA L. 1993 Nomenklatorische und syntaxonomische Definitionen, Konzepte und Methoden. In: Mucina L., Grabherr G.
\& Ellmauer T. (Eds.). Die Pflanzengesellschaften Österreichs, 1, Anthropogene Vegetation: 19-28. G. Fischer, Jena, Stuttgart New York.

31. ZUPANČIĆ M 1986. Prodromus phytocoenosum Jugoslaviae ad mappam vegetationis m 1:200.000. Naučno veće vegetacijske karte Jugoslavije, Bribir-Ilok.

32. Flora Europaea [Internet]. Royal Botanic Garden Edinburgh [cited 2015, Sept. 01]; Available from: http://rbg-web2.rbge.org.uk/ FE/fe.html.

33. BLEČIĆ V, LAKUŠIĆ R 1976 Prodromus biljnih zajednica Crne Gore. Glas. Rep. Zavoda Zašt. Prir. Prirod. Muz. (Titograd) 9: 57-98.

34. MICHL T, DENGLER J, \& HUCK S 2010. Montane-subalpine tall-herb vegetation (Mulgedio-Aconitetea) in central Europe: largescale synthesis and comparison with northern Europe. Phytocoenologia 40 (2-3): 117-154. http://dx.doi.org/10.1127/0340269X/2010/0040-0377

35. RODWELL J S, SCHAMINÉE J H J, MUCINA L, PIGNATTI S, DRING J, MOSS D 2002 The diversity of European vegetation. An overview of phytosociological alliances and their relationships to EUNIS habitats. EC-LNV, Wageningen.

36. LAKUŠIĆ D 2005 Nacionalne klasifikacije staništa. In: LAKUŠIĆ D (ed) Rezultati projekta "Harmonizacija nacionalne nomenklature u klasifikaciji staništa sa standardima međunarodne zajednice", Institut za Botaniku i Botanička Bašta "Jevremovac", Biološki fakultet, Univerzitet u Beogradu, Ministarstvo za nauku i zaštitu životne sredine Republike Srbije, http://habitat.bio.bg.ac.rs/nacionalne_klasifikacije_stanista.htm.

37. DIMOPOULOS, P. AND GEORGIADIS, T., 1995 Present state of the phytosociological research on the Greek mountains, syntaxonomy and future perspectives. Ann. Bot. 53: 119-133.

38. MILOSAVLJEVIĆ V, RANDELOVIĆ V, ZLATKOVIĆ B, RANĐELOVIĆ N 2008 Phytocenologic diversity of Krajište in southeastern Serbia. Natura Montenegrina 7(3): 193-204.

39. PETROVIĆ D, HADŽIABLAHOVIĆ S, VUKSANOVIĆ S, MAČIĆ V, LAKUŠIĆ D 2014 Catalogue of habitat types of EU importance of Montenegro. Podgorica-Beograd-Zagreb, pp. 116.

40. LAKUŠIĆ D, RANDELOVIĆ V 1996 Pregled biljnih zajednica Kopaonika. Ekologija (Beograd) 31(1): 1-16.

41. CONTI F, ABBATE G, ALESSANDRINI A, BLASI C (ed) 2005: An annotated checklist of the Italian vascular flora. Palombi, Roma. pp. 185.

42. TOMOVIĆ G, LAKUŠIĆ D, RANDELOVIĆ V, MARHOLD K 2009 Cardamine amara: L. (Brassicaceae) in Serbia and Republic of Macedonia. Biologia 64(6): 1095-1099. http://dx.doi. org/10.2478/s11756-009-0182-8

43. STEVANOVIĆ, V. 1996: Analysis of the Central European and Mediterranean orophytic element on the mountains of the W. and CentraI Balkan Peninsula, with special reference to endemics. Bocconea, 5 (1): 77-97.

44. SURINA B, PFANZELT S, EINZMANN H J R, ALBACH D C 2014 Bridging the Alps and the Middle East: Evolution, phylogeny and systematics of the genus Wulfenia (Plantaginaceae). Taxon 63(4): 843-858. http://dx.doi.org/10.12705/634.18

45. BRAUN-BLANQUET J. 1964: Pflanzensoziologie. Grundzüge der Vegetationskunde. Springer Verlag Wien. pp. 865 http://dx.doi. org/10.1007/978-3-7091-8110-2 